\title{
Influence of Participative and Achievement Oriented Leadership Styles on Employee Job Satisfaction in Commercial Banks in Kenya
}

\author{
Davidson Mghanga Mwaisaka \\ Prof. George K'Aol \\ Dr. Caren Ouma
}

Chandaria School of Business, United States International University Africa, Kenya

\begin{abstract}
Purpose: The purpose of the study was to examine the influence of participative and achievement-oriented leadership styles on employee job satisfaction in commercial banks in Kenya.

Methodology: The study adopted positivism research philosophy to guide the study and limited itself to descriptive correlational research design to analyze and provide responses to the research questions. The research design was preferred because it allows description and comparison of characteristics of populations based on data collected from samples through questionnaires. The target population of the study was 15,030 employees in all the 43 commercial banks licensed to operate in Kenya as of June 2018. Using stratified sampling technique, the study drew a sample size of 386 employees reporting to middle level managers. Data was collected by means of a questionnaire and analyzed using descriptive and inferential statistics, which included factor analysis, correlational analysis, chi-square, one-way analysis of variance (ANOVA), and regression analysis using Statistical Package for Social Sciences (SPSS) version 20 and Windows' Microsoft excel programs.

Results: Using multiple linear regression analysis, the results of the study confirmed that participative leadership style positively and significantly predicted employee job satisfaction, $\mathrm{R}^{2}=.500, F(1,364)=181.811, p<.05$; $\beta=.673, p<.05$. The study findings of multiple linear regression analysis also revealed that achievement-oriented leadership style positively and significantly predicted employee job satisfaction, $\mathrm{R}^{2}=.507, F(2,366)=$ $190.086, p<.05 ; \beta=.639, p<.05$. From the results of the regression analysis after moderation, it was revealed that environmental contingency factors significantly moderated the relationship between path-goal leadership style
\end{abstract}


and employee job satisfaction, $\mathrm{R}^{2}=0.090, \mathrm{~F}(5,364)=35.04, p<.05 ; \beta=0.229$, $p<.05$.

Unique contribution to theory, practice and policy: The study provides a unique contribution to the theory and practice of path-goal leadership styles in a new perspective in terms how path-goal leadership styles associated with the constructs of participative leadership and achievement oriented leadership styles influence employee job satisfaction in commercial banks of Kenya. Suggestions for future research were made, which included research on the influence of path-goal leadership styles on employee job satisfaction in insurance companies, investment companies, and micro-finance institutions.

Keywords: Participative Leadership, Achievement-Oriented, Path-Goal Leadership Styles, Employee Job Satisfaction.

\subsection{Background}

This study adopted path-goal leadership theory. Path-goal approach to leadership is derived from Vroom's (1964) expectancy theory. According to Alanazi (2013), the path-goal theory makes a clarification on the level of exercising of leadership under differing conditions by a given organization leader. The theory stipulates that there are four leadership styles that organization leadership may adopt. These leadership styles include participative leadership style, supportive leadership style, directive leadership style and achievement-oriented leadership style. Yukl (2013) suggested that the path-goal theory has heavily borrowed from the expectancy theory of motivation especially on the motivational factors that promote the employees in an organization to exert effort in achieving the goals of assigned tasks in order to achieve the targeted outcomes. Yukl further argued that the behaviours of leadership in an organization have a critical role in enhancing motivation of employees to achieve organizational goals. The critical factor for employee job satisfaction is thus dependent on the capability of the leadership to inspire the workers to positively participate in the assigned task.

Mohammad, Nazari and Mehrdad (2013) attempted to establish the relationship between the leadership styles in use in organizations and the job satisfaction of employees in Abuja Nigeria. The study correlated application of path-goal theory by organizational leadership and the levels of job satisfaction. A positive relationship was established highlighting the important role played by leadership style in enhancing employee job satisfaction. Also, Akhigbe, Finelady and Felix (2014) conducted a study on the effects of achievement-oriented leadership style on job satisfaction of selected commercial banks in River State in Nigeria. From the results of the latter study, it was confirmed that achievement oriented leadership style positively and significantly enhance employee job satisfaction. This again highlights the 
fact that leadership style in application in an organization is important in determining job satisfaction.

Otieno, Waiganjo and Njeru (2015) applied path-goal theory to study the relationship between labour relations practices and employee performance in Kenya's horticultural sector. The findings indicated that organizations that had adopted employee engagement strategy had improved their performance. Jeruto (2015) stated that through the path-goal approach, various parameters of job satisfaction amongst employees are established. This is through belief in acceptance of the specified organization goals to be achieved, willingness to put effort to achieve the stated goals and the desire to be part of the team that achieves organization goals. Thus, a significant relationship exists within the organizational leadership in attainment of employee job satisfaction.

\subsection{Problem Statement}

In Kenya, the banking sector is facing a number of performance related challenges characterized by low levels of employee job satisfaction, which is evidenced by high rates of staff turnover. According to the Kenya Bankers Association (2018), the sector has been operating within a tough regulatory framework, which has had negative impact on banks' profitability, endangered job security for employees, jeopardized employee performance, and threatened job satisfaction. The capping of interest rate at $4 \%$ by the 2016 Banking Amendments Act in Kenya led to increased competition in the market. This has witnessed more commercial banks turning to technologies such as mobile banking to lower operating costs and enhance the quality and efficiency of their operations. Adoption of such technologies has resulted in redundancy of more staffs, which affects the levels of job satisfaction of the remaining workforce (Kenya Bankers Association, 2018). Despite all the remedies put in place, Kenyan commercial banks still encounter many challenges as a result of low level employee job satisfaction. A number of studies (Anitha, 2014; Famakin \& Abisuga, 2016; Kagwiria, 2016) have been conducted to determine the influence of leadership styles on bank innovation and performance, but a few studies (Nyaberi \& Kiriago, 2013) examined how innovation in banks affect employee job satisfaction.

A number of local scholars have studied the association of path-goal leadership style and employee job satisfaction (Lumbasi, K'Aol \& Ouma, 2016; Otieno, Waiganjo \& Njeru, 2015; Gitoho, 2015; Nyaberi \& Kiriago, 2013). However, a few scholars have related the impact of path-goal leadership to commercial banks creating a knowledge gap in the sector. As a result of scarcity of local empirical studies, Kagwiria (2016) recommended the need for assessment of viability of use of path-goal leadership style as a solution to organization leadership crises like commercial banks. Apparently, 
knowledge gaps exist in relating the two attributes. This study sought to bridge the knowledge gap.

\subsection{Research Purpose}

This study examined the influence of participative and achievement leadership styles on employee job satisfaction in commercial banks in Kenya.

\subsection{Research Question}

The study was guided by the subsequent question:

1.3.1 How does participative leadership style influence employee job satisfaction in commercial banks in Kenya?

1.3.2 How does achievement-oriented leadership style influence employee job satisfaction in commercial banks in Kenya?

1.3.3 How do environmental contingency factors moderate the relationship between path-goal leadership styles and employee job satisfaction in commercial banks in Kenya?

\subsection{Research Hypotheses}

The study was guided by the subsequent null hypotheses:

$\mathbf{H}_{\mathbf{0 1}}$ : There is no significant influence of participative leadership style on employee job satisfaction in commercial banks in Kenya.

Ho2: There is no significant influence of achievement-oriented leadership style on employee job satisfaction in commercial banks in Kenya.

$\mathbf{H}_{03}$ : Environmental contingency factors do not have significant moderating influence on the relationship between path-goal leadership styles and employee job satisfaction.

\subsection{Synopsis Literature Review}

\subsection{Theoretical Review}

This study adopted path-goal leadership theory as a guiding theory. House and Mitchell (1974) stated that leader behavior refers to the expected code of conduct exhibited by people in power. The leaders provide the expected performance levels, and acceptable means through which those following the leader should use to attain the specified goals. There are four varieties of leadership behaviour and styles postulated: Directive, Supportive, Participative, and Achievement-oriented. Gustafsson and Hornay (2014) state that path-goal leadership styles are the leadership styles pathways model provides. A leader characterized as directive will give his followers detailed instructions on the tasks, the anticipated level of performance, time frames and stringent rules and regulations to observe.

Northouse (2013) argued that environmental factors within the pathgoal theory context are instrumental in determining the suitable leadership 
style to be applied if the best productivity is to be attained from the subordinates. In this case, the environment is seen as constituting external factors beyond the employee's control of the structure of the task system of authority, and work group. House (1971) stated that a leader's behavior will motivate performance amongst employees in relation to the extent in which it facilitates them to cope with relevant environmental uncertainties, threats and frustrations.

\subsection{Conceptual Framework}

Independent Variable

Dependent Variable

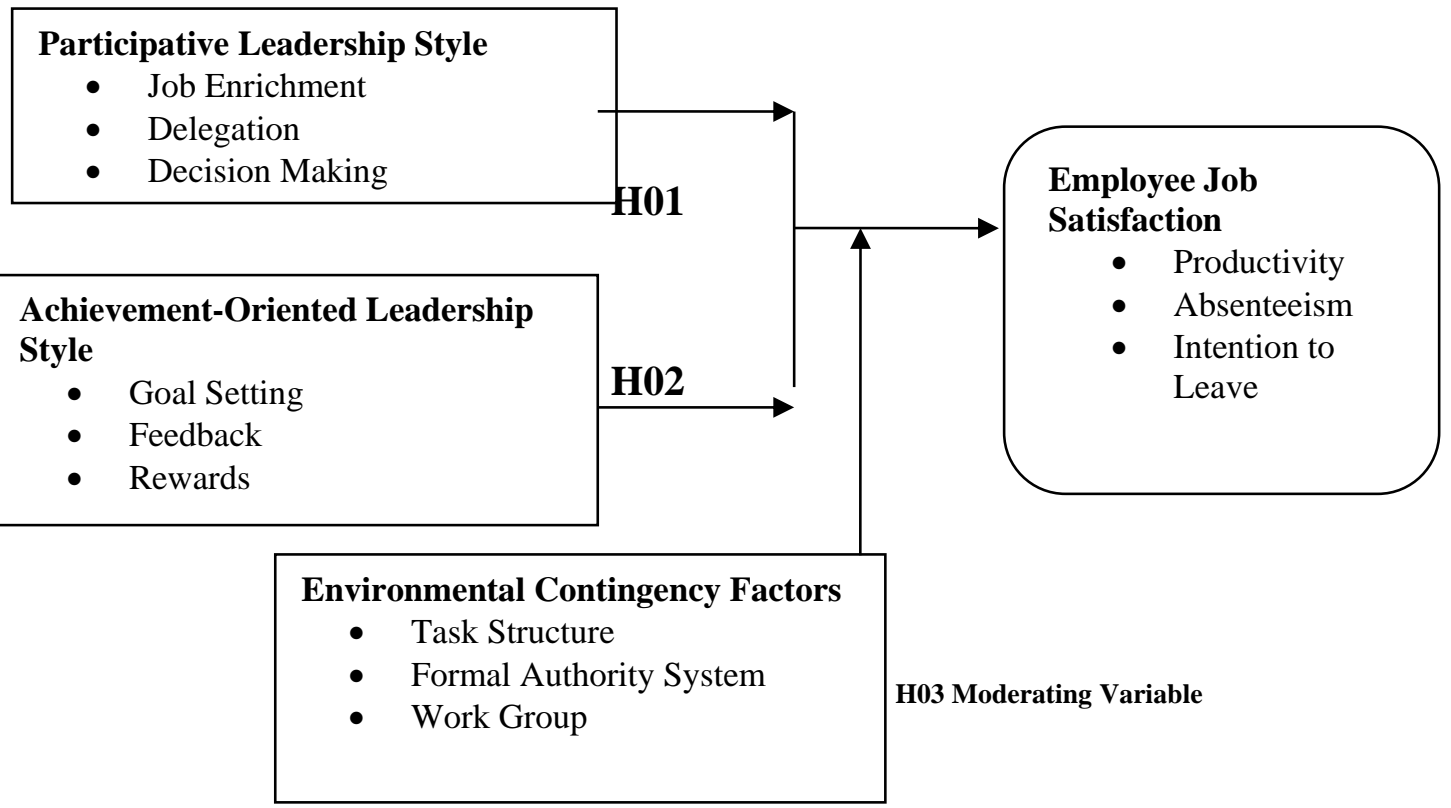

Figure 1: Conceptual Framework

A conceptual framework is a tool for analysis that provides the context of how different variables under study interact (Abend, 2013). The conceptual framework for this study comprises of the independent variables as participative and achievement oriented leadership styles. The dependent variable is job satisfaction amongst employees and the moderating variable is environmental contingency factors. The conceptual framework is shown in Figure 1.

\subsection{Empirical Literature}

\subsubsection{Participative Leadership}

A leadership that can be said to be effective will deliberately seek satisfaction of employees at work, and defines what they expect of each 
employee if the organization is to be successful (Bolman \& Deal, 2013). According to Khuong and Dang (2015), employee reporting high levels of motivation believed they are valued at work and that their work group depend on their performance to attain results. The elements of participative leadership style discussed in this section are; job enrichment, delegation of authority, decision making, creativity and intrinsic motivation.

Participative leadership provides intrinsic motivation to employees by enriching the employees experience at work. The employee is given a higher level of independence at work, variety of choices to accomplish his assignments and develops a sense of empowerment. The employee feels important in an organization when they participate in decision making processes of the organization. This enhances their connection to the organization and inspires them to reach top performance (Yukl, 2013). Yukl further states that participative decision is highly valuable for the organization. It benefits the management, the employees and the organization. Employee's motivation at work is enhanced, innovativeness in the organization increases, and work life balance of the employees is enhanced.

Participative leadership style highly regards delegation of duties and responsibilities. It also involves people in decision making (Dubrin, 2017). Employees feel more satisfied in the work place if they are involved in making key decisions that affect them. When employees feel recognized by the management, their pride and ownership of organizational processes grow (Harter, Schmidt \& Hayes, 2012).

Decisions made in organizations can greatly affect the stability of the organization and the security of employees (Shafritz, 2010). Involving employees in decision making ensures that their relationship with the organizations leadership greatly improves (Robbins, 2014). Leaders grow more respected, and the employees are more embracing of the leadership's direction. This kind of leadership enhances trust between the management and employees. In the contrary, leaders who make decisions by themselves risk losing the support of their employees (Jit, 2013).

\subsubsection{Achievement-Oriented Leadership}

Achievement-oriented leader gives the employees challenging performance targets. The leader seeks continuous performance from their employees and expects high standard performance. This leader will demonstrate great confidence on the employees (Northouse, 2013). Achievement-Oriented leadership is appropriate in circumstances where employees are not highly resistant to autocracy, have an outward focus, and are easy followers of their leadership's direction. It also works when the task is simple and clear, there is high respect for authority, and coworkers commitment to work is high (Lussier \& Achua, 2010). The elements of 
achievement-oriented leadership styles discussed in this section are; employee confidence, strategy execution, goal setting and organization commitment. Moorhead and Griffin (2012) argued that when leaders give subordinates difficult tasks, the employees feel the leaders have confidence in their capabilities. When the employees achieve the duties and are rewarded, it enhances their confidence in the organization (Ratyan \& Mohd, 2013). When goal setting are done right, it enhances employee satisfaction at work (Ashraf et al., 2012). Negron (2008) states that the achievement-oriented leadership style is best suited when the tasks are unclear and where employees need their motivation to be boosted for performance. Research by Titko and Lace (2015) indicated that high achievement-oriented leaders impacted employee's satisfaction of the job, for they are motivated to perform better.

Taris (2016) reports on analysis of relationship between commitment to the organization and achievement-oriented leadership style. From the findings, it is imperative that leaders exhibiting achievement-orientation style connects well with organizations oriented on strategic management. Aziri (2016) studied relationship between motivation of employees in universities and their attachment to their jobs in Nigeria. Further, the findings showed that achievement oriented influenced employee motivation and efficiency of an organization. The recommendation was that heads of departments should have their capacity build on achievement orientation.

Achievement-oriented leaders not only set challenging performance goals for their employees but also for themselves. They also take responsibility for achievement of organizational wide objectives. These leaders are consistent in pursuing achievement of the set performance objectives. The leaders take calculated risks, with the organizational goals in mind. They actively gather information from employees and provide consistent feedback (Suradi, 2017).

Employees with high perceived organizational support feel a heavy responsibility to attain organizational objectives. They have positive attitudes towards their jobs (Robbins, 2014). Suradi (2017) examined and analyzed the association between leadership style, job satisfaction and organization culture among lecturers in Russia. The research object was lecturer in financial education and training agency, Ministry of Finance. The method of this research was explanatory research design. Besides, sampling technique used in this research was saturated sample. On the other hand, statistical analysis used was multiple regression analysis with helping tool like IBM. Findings indicated that leadership style and organizational culture, either holistically or partially, have effects on lecturer's job satisfaction. 


\subsubsection{Environmental Contingency Factors}

Malik (2013) stated that task structure, work group and formal authority are the three categories of environmental contingency factors. Temple's (2013) study examined the job satisfaction of information technology and the effects of such a structure in financial sectors in USA. Organizational structure influences level of motivation and satisfaction of employees. It also had a correlation with employees reward systems in an organization. Structures influenced employee's autonomy, and pathways to objective delivery. Elangovan (2017) examined the association between task orientation, performance and job satisfaction amongst public organizations employees. When employees are satisfied with the job, they perform their duties with greater excellence. There was relationship between level of supervision and job performance. Tomazević, Seljak and Aristovnik (2014) examined factors influencing job satisfaction in police force. It was observed education levels of management and employees significantly influenced the satisfaction levels of the customers.

Yang and Wang (2013) investigated how an employee's attitude regarding authority affected the job satisfaction and how this differed in different cultures. The study found that individual employees regard for authority and job satisfaction was evident. Positive relation between respect for authority and job satisfaction was only partially supported. The relationship between job satisfaction, employee respect for authority and power distance were also only partially supported. Jha (2014) study aimed at examining the job satisfaction and turnover among employees in one of the Malaysian banking institutions. In particular, the study explored the differences between formal authority, intrinsic, and extrinsic satisfaction factors. Intrinsic and extrinsic satisfaction factors are significantly positive where formal authority is perceived.

Ganguly (2015) study investigated composition in work groups in terms of gender influenced employee's satisfaction at work in USA. The findings were that job satisfaction is related to the gender composition of employees in a given work group. However, there were no variations existing among male and female respondents on how the composition affected their satisfaction. Where the groups had gender balance there was greater job satisfaction across genders. Lowest satisfaction was noted in groups dominated by men while groups dominated by women were only averagely satisfied with their jobs.

\subsection{Research Methodology}

Positivism was the research philosophy adopted to guide this study. Positivism is used to support the testing of hypotheses and this is the key reason the philosophy was preferred. The study adopted descriptive 
correlational research design to analyze and provide responses to the research questions. The research design was preferred because it allows description and comparison of characteristics of populations based on data collected from samples through questionnaires. The population of the study consisted of 15,030 employees. A sample size of 386 was drawn using stratified random sampling.

Data was collected using self-administered questionnaires. The data was then analyzed using descriptive statistics of frequency and percentage distribution, mean, and standard deviation. Additionally, inferential data analysis methods were used. These include: factor analysis, Pearson's correlation, ANOVA, and multiple linear regression that were used to test the hypotheses.

\subsection{Research Findings}

This section shows the results of the demographic information of the respondents, participative leadership, achievement oriented leadership and environmental contingency factors. Out of 389 questionnaires, 370 were completed and returned making a $95 \%$ response rate.

\subsection{Demographic Information}

The demographic information of the respondents analyzed included gender of respondents, length of service and level of education. The results show that the majority $(52 \%)$ of the respondents were male while the rest, $48 \%$ were female. From the study, 39\% of respondents had worked for 5-10 years in the organizations, while $28 \%$ had worked for $1-5$ years. In addition, $21 \%$ had worked for over 10 years. Only $11 \%$ had worked for less than one year. The results indicate that overwhelming majority (91\%) of respondents had a first degree level of education.

\subsection{Participative Leadership Style}

\subsubsection{Descriptive Statistics for Participative Leadership}

Descriptive statistical analysis conducted by the study included mean and standard deviation.

The study aimed at examining how the participative leadership style influences employee job satisfaction among employees reporting to middle level managers in the Kenyan banking industry. Means and standard deviations were adopted in providing objective measures of comparison of the data. The Likert scale ranging from $0-4$ where $0=$ Not at all to $4=$ Always was used in the questionnaire whereby the respondents were required to respond to statements by indicating their opinions. The study results are presented in Table 1. 
The findings from the analysis reveal that on average, the supervisor delegates duties and tasks amongst the team members according to the capacity of each team member $(M=2.56, S D=.988)$. The findings also show that that productivity on the job has improved because supervisor asks for suggestions from team members or subordinates concerning how to carryout assignments $(M=2.99, S D=0.986)$.

Table 1: Mean and Standard Deviation for Participative Leadership Style

\begin{tabular}{|l|l|l|l|}
\hline Participative Leadership & N & M & SD \\
\hline $\begin{array}{l}\text { My team leader/supervisor asks for suggestions from team } \\
\text { members or subordinates concerning how to carryout assignments }\end{array}$ & 370 & 2.45 & 1.122 \\
\hline $\begin{array}{l}\text { My team leader/supervisor delegates duties and tasks amongst the } \\
\text { team members according to the capacity of each team member }\end{array}$ & 370 & 2.56 & .988 \\
\hline $\begin{array}{l}\text { My team leader/supervisor involves me in decision making on } \\
\text { how the tasks and duties should be performed effectively }\end{array}$ & 370 & 3.02 & 1.019 \\
\hline Influence of Participative Leadership on Employee Job Satisfaction & & \\
\hline $\begin{array}{l}\text { My productivity on the job has improved because my team } \\
\text { leader/supervisor asks for suggestions from team members or } \\
\text { subordinates concerning how to carryout assignments }\end{array}$ & 368 & 2.99 & .986 \\
\hline $\begin{array}{l}\text { I am rarely absent from work because my team leader/supervisor } \\
\text { delegates duties and tasks amongst the team members according to } \\
\text { the capacity of each team member }\end{array}$ & 368 & 2.63 & .878 \\
\hline $\begin{array}{l}\text { I do not intend to leave the organization because my team } \\
\text { leader/supervisor involves me in decision making on how the } \\
\text { tasks and duties should be performed effectively }\end{array}$ & 368 & 2.49 & 1.280 \\
\hline
\end{tabular}

\subsubsection{Correlating Participative Leadership and Job Satisfaction}

Table 2: Correlation Test for Participative Leadership Style

\begin{tabular}{|l|l|l|l|}
\hline \multirow{2}{*}{ Participative Leadership and Job Satisfaction } & $\begin{array}{l}\text { Participative } \\
\text { Leadership Style }\end{array}$ & $\begin{array}{l}\text { Employee Job } \\
\text { Satisfaction }\end{array}$ \\
\hline \multirow{2}{*}{$\begin{array}{l}\text { Participative } \\
\text { Leadership Style }\end{array}$} & Pearson Correlation & 1 & $.820^{* *}$ \\
\cline { 2 - 4 } & Sig. (2-tailed) & & .000 \\
\cline { 2 - 4 } & $\mathrm{N}$ & 370 & 370 \\
\hline \multirow{2}{*}{$\begin{array}{l}\text { Employee Satisfaction } \\
\text { Job }\end{array}$} & Pearson Correlation & $.820^{* *}$ & 1 \\
\cline { 2 - 4 } & Sig. (2-tailed) & .000 & 370 \\
\cline { 2 - 4 } & $\mathrm{N}$ & 370 & \\
\hline
\end{tabular}

*. Correlation is significant at the 0.05 level (2-tailed).

Correlation refers to a quantitative estimation of the oscillation of two variables with each other. The increase or decrease of two variables in parallel leads to a positive correlation. However, in case one variable increases and the other decreases, then the correlation is negative. In this study, correlation analysis was undertaken to measure the strength of the linear association between the independent and dependent variables. Usually, the Pearson Correlation Coefficient, $r$ values range from +1 to -1 , that is coefficient $r$ may portray either a positive or negative relationship. Table 2 presents the correlation coefficients between study variables. The results show a positive 
significant correlation coefficient between participative leadership style and employee job satisfaction, $r(370)=.820, p<.05$.

\subsubsection{Regression Analysis and Hypothesis Testing}

Multiple linear regression analysis is conducted to examine whether one or more independent/predictor variables cause changes in the dependent variable. A multiple regression analysis was conducted to demonstrate the relationship between the independent variable (participative leadership style) and the dependent variable (employee job satisfaction). Based on a multiple linear regression model, the study sought to determine the influence of participative leadership style on employee job satisfaction among the employees reporting to middle level managers in Kenyan commercial banks. Therefore, the hypothesis tested was:

H01 $_{1}$ : Participative leadership style has no significant influence on employee job satisfaction among employees reporting to middle level managers in commercial banks in Kenya.

The results from regression model summary explain the variations in dependent variable as a result of independent variable. The results in Table 3 show that participative leadership style caused a variation of 50\% in employee job satisfaction among the employees reporting to middle level managers of commercial banks in Kenya, $\mathrm{R}^{2}=.500$. This means that when participative leadership style is applied in commercial banks in Kenya, 50\% variations in employee job satisfaction among the employees reporting to middle level managers in commercial banks in Kenya could be observed.

Table 3: Regression Model Summary for Participative Leadership Style

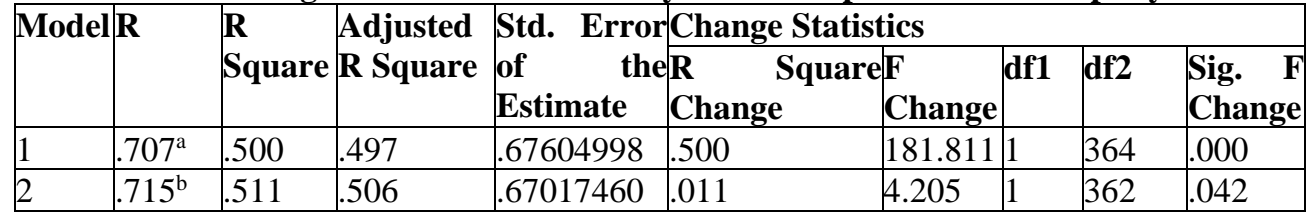

The study findings in Table 4 establish that the relationship between participative leadership style and employee job satisfaction was statistically significant, $F(1,364)=181.811, p<.05$. This means that participative leadership style was a good predictor of employee job satisfaction among employees reporting to middle level managers in the commercial banks in Kenya. Based on the significance of the $F$-statistic, the null hypothesis, participative leadership style has no significant influence on employee job satisfaction among employees reporting to middle level managers in commercial banks in Kenya, was rejected. 
Table 4: ANOVA Test for Participative Leadership Style

\begin{tabular}{|l|l|l|l|l|l|l|}
\hline \multicolumn{2}{|l|}{ Model } & Sum of Squares & Df & Mean Square & F & Sig. \\
\hline \multirow{4}{*}{1} & Regression & 83.095 & 1 & 83.095 & 181.811 & $.000^{\mathrm{b}}$ \\
\cline { 2 - 8 } & Residual & 83.182 & 364 & .457 & & \\
\cline { 2 - 8 } & Total & 166.277 & 366 & & & \\
\hline
\end{tabular}

Multiple linear regression was conducted to assess the direction and extent to which participative leadership style influences employee job satisfaction. The study findings confirmed that participative leadership style significantly predicted employee job satisfaction among employees reporting to middle level managers in the commercial banks in Kenya, $\beta=.673, t(370)$ $=13.484, p<.05$. This meant that a unit change in participative leadership style would lead to an increase in employee job satisfaction among the employees reporting to middle level managers in the banking industry by 0.673 units. Therefore, the study concluded that participative leadership style significantly predicts employee job satisfaction among employees reporting to middle level managers in the commercial banks of Kenya. Table 5 presents the study results.

Table 5: Regression Coefficients for Participative Leadership Style

\begin{tabular}{|c|c|c|c|c|c|c|}
\hline \multirow{2}{*}{\multicolumn{2}{|c|}{ Model }} & \multicolumn{2}{|c|}{\begin{tabular}{|l|} 
Unstandardized \\
Coefficients
\end{tabular}} & \multirow{2}{*}{$\begin{array}{l}\begin{array}{l}\text { Standardized } \\
\text { Coefficients }\end{array} \\
\text { Beta } \\
\end{array}$} & \multirow[t]{2}{*}{$\mathbf{T}$} & \multirow[t]{2}{*}{ Sig. } \\
\hline & & B & Std. Error & & & \\
\hline \multirow[b]{2}{*}{1} & (Constant) & .100 & .050 & & 2.000 & .047 \\
\hline & $\begin{array}{l}\text { Participative } \\
\text { leadership }\end{array}$ & .673 & .050 & .707 & 13.484 & .000 \\
\hline \multirow{3}{*}{2} & (Constant) & .101 & .049 & & 2.039 & .043 \\
\hline & $\begin{array}{l}\text { Participative } \\
\text { leadership } \\
\end{array}$ & .596 & .062 & .626 & 9.592 & .000 \\
\hline & ECFXPL & .130 & .063 & .134 & 2.051 & .042 \\
\hline
\end{tabular}

\subsection{Achievement-Oriented Leadership Style}

\subsubsection{Descriptive Statistics}

Under this variable, descriptive statistical analysis conducted included, mean and standard deviation.

The results indicate that on average, the supervisor sets challenging goals for employee duties and tasks $(M=2.61, S D=.984)$. It was also found that employees productivity on the job had improved because supervisors sets challenging goals for employee duties and tasks $(M=2.97, S D=0.966)$. The study results are presented in Table 6 . 
Table 6: Mean and Standard Deviation for Achievement-Oriented Leadership

\begin{tabular}{|l|l|l|l|}
\hline Achievement Oriented Leadership & N & M & SD \\
\hline $\begin{array}{l}\text { My team leader/supervisor sets challenging goals for my duties } \\
\text { and tasks }\end{array}$ & 370 & 2.62 & \multicolumn{2}{l|}{$\begin{array}{l}1.17 \\
0\end{array}$} \\
\hline $\begin{array}{l}\text { My team leader/supervisor gives feedback for continuous } \\
\text { improvement on job performance }\end{array}$ & 370 & 2.61 & .984 \\
\hline $\begin{array}{l}\text { My team leader/supervisor encourages team members to perform } \\
\text { their duties and tasks at the highest level of their abilities }\end{array}$ & 370 & 2.98 & 1.04 \\
\hline Influence of Achievement Oriented Leadership on Employee Job Satisfaction \\
\hline $\begin{array}{l}\text { My productivity on the job has improved because my team } \\
\text { leader/supervisor sets challenging goals for my duties and tasks }\end{array}$ & 370 & 2.97 & .966 \\
\hline $\begin{array}{l}\text { I am rarely absent from work because my team leader/supervisor } \\
\text { gives feedback for continuous improvement on job performance }\end{array}$ & 370 & 2.76 & .954 \\
\hline $\begin{array}{l}\text { I do not intend to leave the organization because my team } \\
\text { leader/supervisor encourages team members to perform their } \\
\text { duties and tasks at the highest level of their abilities }\end{array}$ & 370 & 2.63 & 1.26 \\
\hline
\end{tabular}

\subsubsection{Correlation between Achievement Oriented Leadership Influence on Employee job satisfaction}

Correlation refers to a quantitative estimation of the oscillation of two variables with each other. The increase or decrease of two variables in parallel leads to a positive correlation. However, in case one variable increases and the other decreases, then the correlation is negative. In this study, correlation analysis was undertaken to measure the strength of the linear association between the independent and dependent variables. Usually, the Pearson Correlation Coefficient, $r$ values range from +1 to -1 , that is coefficient $r$ may portray either a positive or negative relationship. Table 7 presents the correlation coefficients between study variables. The results show that there was a positive significant correlation coefficient between achievementoriented leadership style and employee job satisfaction $r(370)=0.805, p<$ .05 .

Table 7: Correlation Test for Achievement-Oriented Leadership Style

\begin{tabular}{|l|l|l|l|}
\hline \multicolumn{3}{|l|}{ Correlations } \\
\hline $\begin{array}{l}\text { Achievement Oriented Leadership Style } \\
\text { and Job Satisfaction }\end{array}$ & $\begin{array}{l}\text { Achievement- } \\
\text { Oriented Leadership } \\
\text { Style }\end{array}$ & $\begin{array}{l}\text { Employee Job } \\
\text { Satisfaction }\end{array}$ \\
\hline $\begin{array}{l}\text { Achievement-Oriented } \\
\text { Leadership Style }\end{array}$ & $\begin{array}{l}\text { Pearson } \\
\text { Correlation }\end{array}$ & $.805^{* *}$ \\
\cline { 2 - 4 } & Sig. (2-tailed) & & .000 \\
\cline { 2 - 4 } & $\mathrm{N}$ & 370 & 370 \\
\hline $\begin{array}{l}\text { Employee Job } \\
\text { Satisfaction }\end{array}$ & $\begin{array}{l}\text { Pearson } \\
\text { Correlation }\end{array}$ & $.805^{* *}$ & 1 \\
\cline { 2 - 4 } & Sig. (2-tailed) & .000 & 370 \\
\cline { 2 - 4 } & $\mathrm{N}$ & 370 & \\
\hline
\end{tabular}

* Correlation is significant at the 0.05 level (2-tailed). 


\subsubsection{Regression Analysis and Hypothesis Testing}

Multiple linear regression analysis is conducted to examine whether one or more independent/predictor variables cause changes in the dependent variable. A multiple regression analysis was conducted to demonstrate the relationship between the independent variable (directive leadership style) and the dependent variable (employee job satisfaction). Based on a multiple linear regression model, the study sought to determine the influence of achievementoriented leadership style on employee job satisfaction among the employees reporting to middle level managers in Kenyan commercial banks. Therefore, the hypothesis tested was:

$\mathbf{H O}_{2}$ : Achievement-Oriented leadership style has no significant influence on employee job satisfaction among employees reporting to middle level managers in commercial banks in Kenya.

The results from regression model summary explain the variations in dependent variable as a result of independent variable. The results in Table 8 show that achievement-oriented leadership style caused a variation of 50.9\% in employee job satisfaction among the employees reporting to middle level managers of commercial banks in Kenya, $\mathrm{R}^{2}=.509$. This means that when achievement-oriented leadership style is applied in commercial banks in Kenya, 50.9\% variations in employee job satisfaction among the employees reporting to middle level managers in commercial banks in Kenya could be observed.

Table 8: Regression Model Summary for Achievement-Oriented Leadership Style

\begin{tabular}{|c|c|c|c|c|c|c|c|c|c|}
\hline \multirow{3}{*}{\begin{tabular}{|l|} 
Mod \\
el
\end{tabular}} & \multirow{3}{*}{\multicolumn{2}{|c|}{\begin{tabular}{|l|l|}
$\mathbf{R}$ & $\begin{array}{l}\mathbf{R} \\
\text { Squar } \\
\mathbf{e}\end{array}$ \\
\end{tabular}}} & \multirow{3}{*}{$\begin{array}{l}\text { Adjusted } \\
\text { R Square }\end{array}$} & \multicolumn{6}{|c|}{ Std. Error|Change Statistics } \\
\hline & & & & of & & Square $\mathbf{F}$ & df1 & df2 & Sig. \\
\hline & & & & Estimate & Change & Change & & & Change \\
\hline 1 & & $4^{\mathrm{a}} \cdot .509$ & .507 & .62820778 & .509 & 190.086 & 1 & 366 & .000 \\
\hline 2 & .72 & $4^{\mathrm{b}} \cdot .524$ & .519 & .62061748 & .014 & 5.504 & 1 & 364 & .020 \\
\hline
\end{tabular}

The study results in Table 9 demonstrate that the relationship between achievement-oriented leadership style and employee job satisfaction among employees reporting to middle level managers in commercial banks was significant, $F(2,366)=190.086, p<.05$. These findings implied that the overall model was significant in associating achievement-oriented leadership style and employee job satisfaction among the managers of commercial banks. The findings also demonstrated that achievement-oriented leadership style was a good predictor of employee job satisfaction among the employees reporting to middle level managers in the commercial banks in Kenya. The study hence concluded that the model was significant in explaining the relationship between the independent variable (achievement-oriented leadership style) and the dependent variable (employee job satisfaction). Considering the significance of the $F$-statistic, the null hypothesis, 
achievement-oriented leadership style has no significant influence on employee job satisfaction among employees reporting to middle level managers of Kenyan commercial banks, was rejected.

Table 9: ANOVA Test for Achievement-Oriented Leadership Style

\begin{tabular}{|l|l|l|l|l|l|l|}
\hline \multicolumn{2}{|l|}{ Model } & Sum of Squares & Df & Mean Square & F & Sig. \\
\hline \multirow{3}{*}{1} & Regression & 75.016 & 2 & 75.016 & 190.086 & $.000^{\mathrm{b}}$ \\
\cline { 2 - 8 } & Residual & 72.220 & 366 & .395 & & \\
\cline { 2 - 8 } & Total & 147.236 & 368 & & & \\
\hline
\end{tabular}

Regression coefficient refers to the slope as indicated by the linear relationship between the independent and the dependent variables. Multiple linear regression was conducted to examine the magnitude and direction of the relationship between achievement-oriented leadership style and employee job satisfaction. The study findings confirmed that achievement-oriented leadership style significantly predicted employee job satisfaction among employees reporting to middle level managers in the commercial banks in Kenya, $\beta=.639, t(370)=13.787, p<.05$. This implied that a unit change in achievement-oriented leadership style would lead to an increase in employee job satisfaction among the employees reporting to middle level managers in the banking industry by 0.639 units. As a result, the study concluded that achievement-orientated leadership style significantly predicts employee job satisfaction among employees reporting to middle level managers in the commercial banks of Kenya. Table 10 presents the study results.

Table 10: Regression Coefficients for Achievement-Oriented Leadership

\begin{tabular}{|c|c|c|c|c|c|c|}
\hline \multirow{2}{*}{\multicolumn{2}{|c|}{ Model }} & \multicolumn{2}{|c|}{\begin{tabular}{|l|} 
Unstandardized \\
Coefficients
\end{tabular}} & \multirow{2}{*}{\begin{tabular}{|l|}
$\begin{array}{l}\text { Standardized } \\
\text { Coefficients }\end{array}$ \\
Beta \\
\end{tabular}} & \multirow[t]{2}{*}{$\mathbf{T}$} & \multirow[t]{2}{*}{ Sig. } \\
\hline & & $\mathbf{B}$ & Std. Error & & & \\
\hline \multirow{2}{*}{1} & (Constant) & .101 & .046 & & 2.194 & .030 \\
\hline & Achievement Oriented leadership & .639 & .046 & .714 & 13.787 & .000 \\
\hline & (Constant) & .047 & .051 & & .912 & .363 \\
\hline & Achievement Oriented leadership & .633 & .046 & .708 & 13.821 & .000 \\
\hline & AOLXECF & .097 & .041 & .120 & 2.346 & .020 \\
\hline
\end{tabular}

\subsection{Moderating Influence of Environmental Contingency Factors 4.3.1 Descriptive Statistics}

The study in this sub-section conducted descriptive analysis namely; mean and standard deviation. The findings in Table 11 indicate that generally, the supervisor built a team of staff who worked on tasks together $(M=2.84$, $S D=1.035)$. The study results also show that employee productivity on the job had improved because their supervisor provided a detailed job description and procedures for their tasks and duties $(M=2.83, S D=.971)$. 
Table 11: Mean and Standard Deviation for Environmental Contingency Factors

\begin{tabular}{|l|l|l|l|}
\hline Environmental Contingency Factors & N & M & SD \\
\hline $\begin{array}{l}\text { My team leader/supervisor provides a detailed job description and } \\
\text { procedures for my tasks and duties }\end{array}$ & 370 & 2.38 & 1.122 \\
\hline $\begin{array}{l}\text { My team leader/supervisor ensures there are processes in place } \\
\text { that enables me to carry out my tasks and duties without the need } \\
\text { to consult others }\end{array}$ & 370 & 2.36 & 1.044 \\
\hline $\begin{array}{l}\text { The team leader/supervisor builds a team of staff who work on } \\
\text { tasks together }\end{array}$ & 370 & 2.84 & 1.035 \\
\hline Influence of Environmental Contingency Factors on Employee Job Satisfaction \\
\hline $\begin{array}{l}\text { My productivity on the job has improved because my team } \\
\text { leader/supervisor provides a detailed job description and } \\
\text { procedures for my tasks and duties }\end{array}$ & 368 & 2.83 & .971 \\
\hline $\begin{array}{l}\text { I am rarely absent from work because my team leader/supervisor } \\
\text { ensures there are processes in place that enables me to carry out } \\
\text { my tasks and duties without the need to consult others }\end{array}$ & 368 & 2.53 & .862 \\
\hline $\begin{array}{l}\text { I do not intend to leave the organization because my team } \\
\text { leader/supervisor builds a team of staff who work on tasks } \\
\text { together }\end{array}$ & 368 & 2.33 & 1.278 \\
\hline
\end{tabular}

\subsubsection{Correlation between Environmental Contingency Factors and Employee Job Satisfaction}

Table 12: Correlation Test for Environmental Contingency Factors

\begin{tabular}{|c|c|c|c|}
\hline \multicolumn{4}{|l|}{ Correlations } \\
\hline \multicolumn{2}{|c|}{$\begin{array}{l}\text { Environmental Contingency Factors and } \\
\text { Job Satisfaction }\end{array}$} & $\begin{array}{l}\text { Environmental } \\
\text { Contingency } \\
\text { Factors }\end{array}$ & $\begin{array}{l}\text { Employee Job } \\
\text { Satisfaction }\end{array}$ \\
\hline \multirow{3}{*}{$\begin{array}{l}\text { Environmental } \\
\text { Contingency Factors }\end{array}$} & $\begin{array}{l}\text { Pearson } \\
\text { Correlation }\end{array}$ & 1 & $.817^{* * *}$ \\
\hline & Sig. (2-tailed) & & .000 \\
\hline & $\mathrm{N}$ & 370 & 370 \\
\hline \multirow[t]{3}{*}{$\begin{array}{l}\text { Employee } \\
\text { Satisfaction }\end{array}$} & $\begin{array}{l}\text { Pearson } \\
\text { Correlation }\end{array}$ & $.817^{* * *}$ & 1 \\
\hline & Sig. (2-tailed) & .000 & \\
\hline & $\mathrm{N}$ & 370 & 370 \\
\hline
\end{tabular}

* Correlation is significant at the 0.05 level (2-tailed).

Correlation refers to a quantitative estimation of the oscillation of two variables with each other. The increase or decrease of two variables in parallel leads to a positive correlation. However, in case one variable increases and the other decreases, then the correlation is negative. In this study, correlation analysis was undertaken to measure the strength of the linear association between the moderating and dependent variables. Usually, the Pearson Correlation Coefficient, $r$ values range from +1 to -1 , that is coefficient $r$ may portray either a positive or negative relationship. 
Table 12 presents the correlation coefficients between study variables. The results showed that the there was a positive significant correlation coefficient between employee job satisfaction and environmental contingency factors $r(370)=0.817, p<.05$.

\subsubsection{Regression Analysis and Hypothesis Testing}

The study sought to establish the moderating influence of environmental contingency factors on the relationship between path-goal leadership styles and job satisfaction of employees reporting to middle level managers at commercial banks in Kenya. The hypothesis tested was:

H3: Environmental contingency factors do not have a significant moderating influence on the relationship between path-goal leadership styles and employee job satisfaction.

The results from regression model summary explain the variations in dependent variable as a result of independent variable. The results in Table 13 show that environmental contingency factors caused a variation of $9 \%$ in moderating the relationship between path-goal leadership styles and employee job satisfaction among the employees reporting to middle level managers of commercial banks in Kenya, $\mathrm{R}^{2}=.090$. This implies that when environmental contingency factors are applied in commercial banks in Kenya, 9\% variations in moderation of relationship between path-goal leadership styles and employee job satisfaction among the employees reporting to middle level managers in commercial banks in Kenya could be observed.

Table 13: Regression Model after Moderation

\begin{tabular}{|c|c|c|c|c|c|c|c|c|c|}
\hline \multirow[b]{2}{*}{$\frac{\bar{g}}{8}$} & \multirow[b]{2}{*}{$\simeq$} & \multirow[b]{2}{*}{ 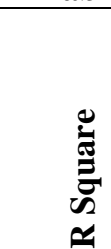 } & \multirow{2}{*}{ 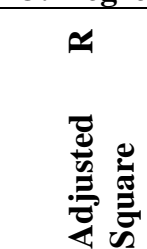 } & \multirow{2}{*}{ 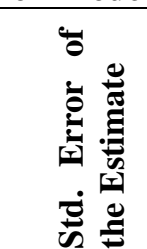 } & \multicolumn{5}{|c|}{ Change Statistics } \\
\hline & & & & & 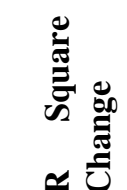 & 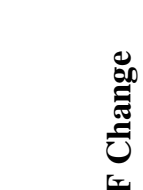 & $\bar{\Xi}$ & $\mathfrak{S}$ & 工茄 \\
\hline 1 & $\begin{array}{l}.853 \\
\mathrm{a} \\
\end{array}$ & .799 & .761 & .587 & .799 & $\begin{array}{l}3057.50 \\
4 \\
\end{array}$ & 4 & $\begin{array}{l}36 \\
5\end{array}$ & $\begin{array}{l}2.00 \\
0\end{array}$ \\
\hline 2 & .942 & .889 & .850 & .358 & .090 & $\begin{array}{l}3167.11 \\
7\end{array}$ & 1 & $\begin{array}{l}36 \\
4\end{array}$ & $\begin{array}{l}.00 \\
0 \\
\end{array}$ \\
\hline
\end{tabular}

a. Predictors: (Constant), Achievement-Oriented Leadership Style, Directive Leadership Style, Participative Leadership Style, Supportive Leadership Style

b. Predictors: (Constant), Achievement-Oriented Leadership Style, Directive Leadership Style, Participative Leadership Style, Supportive Leadership Style, Environmental Contingency Factors 
Table 14: Regression ANOVA

\begin{tabular}{|l|l|l|l|l|l|l|}
\hline \multicolumn{2}{|l|}{ Model } & Sum of Squares & Df & Mean Square & F & Sig. \\
\hline \multirow{1}{*}{$\mathbf{1}$} & Regression & $\mathbf{1 0 7 . 3 1 1}$ & $\mathbf{4}$ & $\mathbf{2 6 . 8 2 8}$ & $\mathbf{3 0 . 5 7}$ & $\mathbf{. 0 0 0}^{\mathbf{b}}$ \\
\cline { 2 - 8 } & Residual & 3.203 & 365 & .009 & & \\
\cline { 2 - 8 } & Total & 110.514 & 369 & & & \\
\hline \multirow{2}{*}{2} & Regression & 110.514 & 5 & 22.103 & 35.04 & $.000^{\text {c }}$ \\
\cline { 2 - 8 } & Residual & .000 & 364 & .000 & & \\
\cline { 2 - 8 } & Total & 110.514 & 369 & & & \\
\hline
\end{tabular}

a. Dependent Variable: Employee Job Satisfaction

b. Predictors: (Constant), Achievement-Oriented Leadership Style, Directive Leadership Style, Participative Leadership Style, Supportive Leadership Style

c. Predictors: (Constant), Achievement-Oriented Leadership Style, Directive Leadership Style, Participative Leadership Style, Supportive Leadership Style, Environmental Contingency Factors

The study results in Table 14 demonstrate that the moderating influence of environmental contingency factors between path-goal leadership style and employee job satisfaction among employees reporting to middle level managers in commercial banks was significant, $F(5,364)=35.04, p<$ .05. These findings implied that the overall model was significant in associating environmental contingency factors, path-goal leadership style and employee job satisfaction among the managers of commercial banks. The findings also demonstrated that environmental contingency factors were a good predictor of path-goal leadership styles and employee job satisfaction among the employees reporting to middle level managers in the commercial banks of Kenya. The study hence concluded that the model was significant in explaining the relationship between the independent variable (path-goal leadership styles) and the dependent variable (employee job satisfaction). Considering the significance of the $F$-statistic, the null hypothesis, environmental contingency factors do not have significant influence on the relationship between path-goal leadership styles and employee job satisfaction among employees reporting to middle level managers in commercial banks in Kenya, was rejected

Regression coefficient refers to the slope as indicated by the linear relationship between the independent and the dependent variables. Multiple linear regression was conducted with an aim of examining how environmental contingency factors moderate the relationship between path-goal leadership styles and employee job satisfaction. The study findings confirmed that environmental contingency factors significantly moderate the relationship between path-goal leadership styles and employee job satisfaction among employees reporting to middle level managers in the commercial banks in Kenya, $\beta=0.229, t(370)=184.763$. The implication is that a unit increase in environmental contingency factors leads to an increase among the job satisfaction of employees by 0.419 units. As a result, the study concluded that 
environmental contingency factors significantly moderate the relationship between path-goal leadership styles and employee job satisfaction among employees reporting to middle level managers in the commercial banks in Kenya. Table 15 presents the study results.

Table 15: Regression coefficients

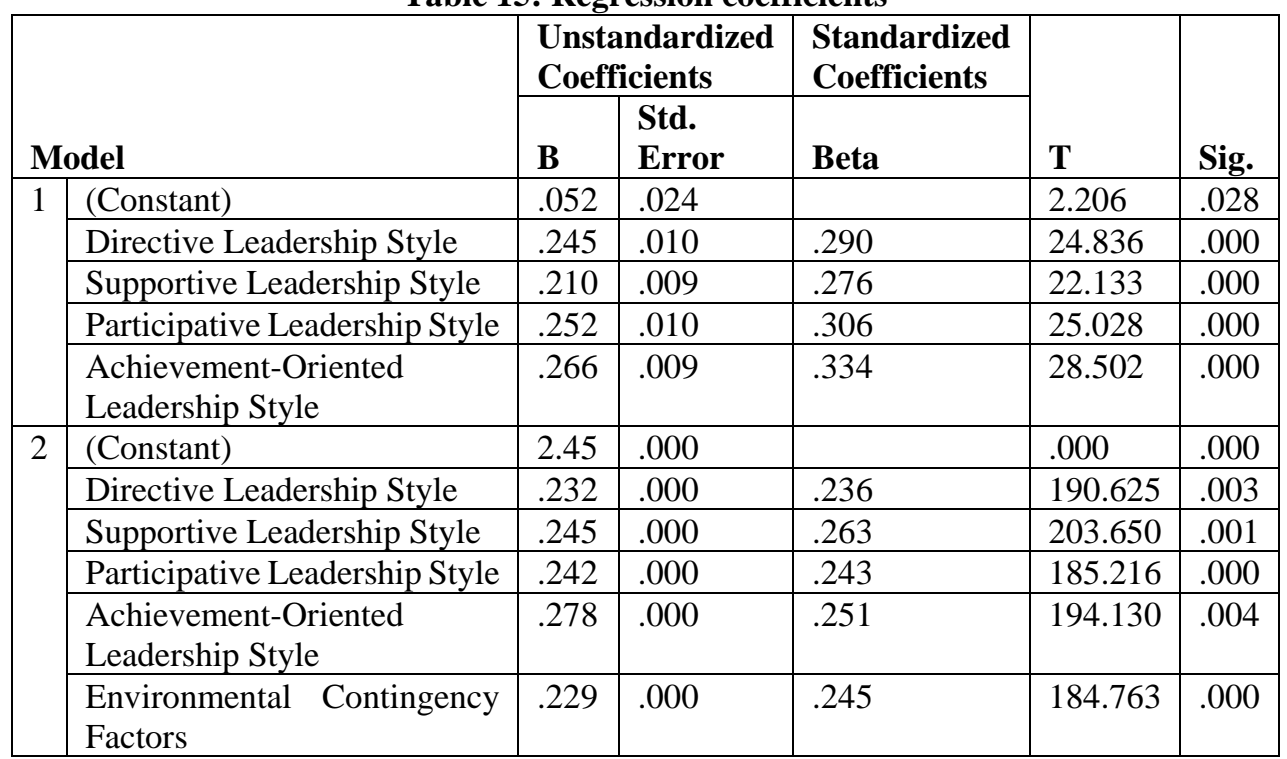

a. Dependent Variable: Employee Job Satisfaction

\subsection{DISCUSSION, CONCLUSIONS AND RECOMMENDATIONS \\ 5.1 Discussion}

\subsubsection{Participative Leadership Style and Employee Job Satisfaction}

The study sought to establish the influence of participative leadership style on job satisfaction in commercial banks in Kenya. The findings from correlation analysis showed positive significant correlation coefficient between participative leadership style and employee job satisfaction, $r(370)=$ $.820, p<.05$. The findings agree with Lamb (2013) states that participative leadership encourage all employees to actively participate in various aspects of running the organization making them feel relevant. Polston-Murdoch (2013) found that a manager oriented to participative leadership is deliberate about employee involvement which improves their commitment and enhances partnership amongst them. The result is better quality and sustainable decisions. The satisfaction at work is improved.

Correlation analysis established that there was a positive significant correlation coefficient between employee job satisfaction and team leader/supervisor asking for suggestions from team members or subordinates concerning how to carry out assignments $r(370)=0.507, p<.05$. The finding agrees with Yukl (2013) position that participative leadership style is keen on 
motivating employees from deep within by job enrichment. Job enrichment is attained by such things as increased autonomy at work, being offered a variety of paths to choose from in doing work and general empowerment. The implication is that employees in commercial banks are democratically engaged in making thus decisions making them feel connected to the organization.

\subsubsection{Achievement Oriented Leadership Style and Job Satisfaction}

The study sought to establish the influence of achievement oriented leadership style on job satisfaction among employees reporting to middle level managers in commercial banks in Kenya. The results from correlation analysis showed that there was a positive significant correlation coefficient between achievement-oriented leadership style and employee job satisfaction $r(370)=$ $0.805, p<.05$. The findings support Ratyan and Mohd (2013) suggestion that setting challenging goals and providing constant feedback to the employees by achievement oriented leaders assist in showing that the leader has confidence in them. The implication is that achievement oriented leadership is connected to reward systems for motivational purposes when the set targets are met resulting in job satisfaction for employees.

Correlation analysis established significant positive relationship existed between achievement oriented leadership style of the manager and employee job satisfaction. For example, there was a positive significant correlation coefficient between employee job satisfaction and team leader/supervisor setting challenging goals for duties and tasks $r(370)=0.555$, $p<.05$. The findings support the statement that goal setting in the organization has great impact and significant positive correlation with employee organizational commitment, that eventually lead to enhanced employee job satisfaction (Ashraf et al., 2012). Furthermore, achievement guided kind of leadership is best positioned when goals, task clarity is poor, employee are demotivated, or they need a boost in their confidence. Further, achievementoriented leadership style suit with unclear tasks and employees who may need a morale booster through rewards to increase their confidence in ability to accomplish the given goal.

\subsubsection{Environmental Contingency Factors and Employee Job Satisfaction}

Environmental contingency factors were the moderating variable in this study. The correlation analysis showed that there prevailed a strong and positive relationship between environmental contingency factors and employee job satisfaction, $r(370)=.817, p<.05$. This agree with Northhouse (2013) that where uncertainties are present, environmental contingency factors such as formal authority system through achievement oriented, directive, 
supportive and participative leaders assist in enhancing employee job satisfaction.

The study revealed a significant correlation between task structure and employee job satisfaction, $r(370)=.505, p<.05$. A study by Temple (2013) confirmes that organizational structure influences level of motivation and satisfaction of employees. It also had a correlation with employees reward systems in an organization. Structures influenced employee's autonomy, and pathways to objective delivery. Elangovan (2017) study on the association between task orientation, performance and job satisfaction amongst public organizations employees. When employees are satisfied with the job, they perform their duties with greater excellence. There was a relationship between level of supervision and job performance. Tomazevic, Seljak and Aristovnik (2014) examined factors influencing job satisfaction in police force. It was observed that education levels of management and employees significantly influenced the satisfaction levels of the customers.

\subsection{Conclusion}

\subsubsection{Participative Leadership Style}

The study investigated the influence of participative leadership style on employee job satisfaction among employees reporting to middle level managers in commercial banks in Kenya. The results from multiple linear regression analysis revealed that participative leadership style positively and significantly predicted employee job satisfaction among employees reporting to middle level managers at commercial banks in Kenya.

\subsubsection{Achievement Oriented Leadership Style}

The study sought to establish the influence of achievement oriented leadership style on job satisfaction among employees reporting to middle level managers in commercial banks in Kenya. The results from multiple linear regression analysis established that achievement-oriented leadership style positively and significantly predicted employee job satisfaction among employees reporting to middle level managers at commercial banks in Kenya.

\subsubsection{Moderating Influence of Environmental Contingency Factors}

The study established that environmental contingency factors significantly influenced the relationship between path-goal leadership style and employee job satisfaction among employees reporting to middle level managers in commercial banks in Kenya. The results from the multiple linear regression analysis revealed that environmental contingency factors significantly moderated the relationship between path-goal leadership style and employee job satisfaction among employees reporting to middle level managers in the commercial banks in Kenya. 


\subsection{Recommendations}

\subsubsection{Participative Leadership Style}

The study found that there was significant influence of participative leadership style on job satisfaction of employees reporting to middle level managers in commercial banks in Kenya. This shows that involvement of employees, especially employees reporting to middle level managers in organization's decision making process is essential in enhancing job satisfaction in commercial banks in Kenya. Team leaders should be asking for suggestions from team members concerning how to carry out assignments before directing them on how to do the assignments.

\subsubsection{Achievement Oriented Leadership Style}

The study found that there was significant influence of achievementoriented leadership style on job satisfaction among employees reporting to middle level managers in commercial banks in Kenya. Supervisors should be setting challenging goals for the duties of employees and be giving feedback for continuous improvement on the job performance.

\subsubsection{Moderating Effect of Environmental Contingency Factors}

The study established that environmental contingency factors significantly influenced the relationship between path-goal leadership style and employee job satisfaction among employees reporting to middle level managers in commercial banks in Kenya. Team leaders should be providing detailed job description and procedures for the employee tasks and duties to enhance job productivity.

\subsubsection{Suggestions for Further Research}

The target population for this study was middle level managers. Even though middle level managers are more involved in supervising the execution of orders from top management, lower level employees would have provided more crucial information about their job satisfaction levels as they are the very people that execute the decisions made by top management. The study hence recommends the inclusion of all employees in the process of determining the influence of path-goal leadership style on employee job satisfaction.

\section{References:}

1. Abend, G. (2013). The Meaning of Theory: Sociological Theory. San Francisco, CA: Berrett-Koehler Publishers.

2. Akhigbe, J. O., Finelady, M. A., \& Felix, O. O. (2014). Transactional Leadership Style and Employee Satisfaction in Nigerian Banking Sector. European Journal of Business and Management, Vol. 6(26), 15-23. 
3. Alanazi, E. (2013). Overview of path-goal leadership theory. Sains Humanika 64 (2), 1-2.

4. Anitha, M. (2014). Determinants of employee engagement and their impact on employee performance. International Journal of Productivity and Performance Management, 63(3), 308-323.

5. Ashraf MA, Ahmad MSA, Ashraf M, Al-Qurainy F, Ashraf MY (2012). Alleviation of waterlogging stress in upland cotton (Gossypium hirsutum L.) by exogenous application of potassium in soil and as a foliar spray. Crop Pasture Sci., 62(1): 25-38.

6. Aziri B. (2016). Job satisfaction: A Literature Review. Management Research And Practice, 3 (4), 77-86

7. Bolman, \& Deal. (2013). Leadership and Management Model. European Journal of Business and Strategic Management, 1, (1), 1-6.

8. Dubrin, A. (2015). Leadership: Research findings, practice, and skills. New York: Nelson Education Publishers.

9. Elangovan, A. R. (2017). Causal ordering of stress, satisfaction and commitment, and intention to quit: a structural equations analysis. Leadership \& Organization Development Journal, 22(4), 159-165.

10. Famakin, I., \& Abisuga A. (2016). Effect of path-goal leadership styles on the commitment of employees on construction projects. International Journal of Construction Management, 16 (2)10-11.

11. Ganguly R. (2015). Composition of work groups, Quality of work life and job satisfaction of employees in USA. Asian Journal of Management Research, 1 (8), 2229 - 3795.

12. Gustafsson, J., \& Hornay. P. (2014). Leadership Driving Successful Implementation of Continuous Improvement Programs- A Case Study Using the Path Goal Model. Master Thesis, Technology Management$\mathrm{Nr}$ 282/2015, University of Sweden.

13. Harter, J. K., Schmidt, F. L., \& Hayes, T. L. (2012). Business-unitlevel relationship between employee satisfaction, employee engagement, and business outcomes: A meta-analysis. Journal of Applied Psychology, 8 (5), 268-279

14. House, R. (1971). A Path-Goal Theory of Leader Effectiveness. Administrative Science Quarterly, 16, 321-328.

15. House, R. J., \& Mitchell, T. R. (1974). Path-goal theory of leadership. Journal of Contemporary Business, Journal of Humanities, 3 (1) 1-97.

16. Jeruto, K. (2015). Organizational commitment and job satisfaction in higher educational institutions: the Kenyan case. $\mathrm{PhD}$ thesis, Middlesex University.

17. Jha, S. (2014). Determinants of employee turnover intentions. Organization Development Journal, 2(1), 15-16. 
18. Jit, S. C. (2013). Organizational Behavior, (3 ${ }^{\text {rd }}$ Ed.). VIKAS Publishing House, Reprint.

19. Kagwiria, L., (2016). Influence of Leadership on Employee Productivity at KCB Bank Kenya Ltd. Nairobi Branches, University of Nairobi.

20. Kenya Bankers Association, (2018). Annual Report. Government Press.

21. Khuong, M. N. \& Dang, T. H. (2015). The Effects of Leadership Styles on Employee Motivation in Auditing Organizations in Ho Chi Minh City, Vietnam, International Journal of Trade, Economics and Finance, 6 (7), 12-14.

22. Lamb, R. (2013). How can Managers Use Participative Leadership Effectively? Retrieved January 1, 2018, from http://www.achievement.fm/participative-leadership.

23. Lumbasi, G. W., K'Aol, G. O., \& Ouma, C. A. (2016). The effect of achievement oriented leadership style on the performance of COYA Senior Managers in Kenya. International Journal of Novel Research in Marketing Management and Economics, 3(2), 118-125

24. Lussier, N. R., \& Achua, C. F. (2010). Effective Leadership. London: Thomson South-Western.

25. Malik, S. H. (2013). Leadership Behavior and Employee Job Satisfaction: A Study of Path-Goal Theory in Telecom Sector. (Unpublished doctoral dissertation) Islamabad: National University of Modern Languages.

26. Mohammad, V. Nazari, A. A., \& Mehrdad, G. C. (2013). The relationship between employees empowerment with job satisfaction in Melli Bank of Guilan Province. Arabian Journal of Business and Management Review (OMAN Chapter) 2 (12), 71-73.

27. Moorhead., G \& Griffin R. (2012). Managing Organizational Behavior, South-Western Cengage Learning.

28. Negron, D. (2008). A case study examining the relationship of the path-goal theory leadership styles to profits in El Paso, Texas, RentA-Center stores. Capella: Capella University.

29. Northouse, P. (2013). Leadership Theory and Practice. Thousand Oaks: Sage Publications, Inc.

30. Nyaberi, E. N., \& Kiriago, A. N. (2013). Effects of Retrenchment on the Morale and Job Security of Surviving Employees in Kenya. London: Sage Publications.

31. Otieno, B. B. A., Waiganjo, E. W., \& Njeru, A. (2015). Effect of Employee Engagement on Organization Performance in Kenya's Horticultural Sector. International Journal of Business Administration, 6(2), 1-4. 
32. Polston-Murdoch, L. (2013). An Investigation of path-goal theory, relationship of leadership style, supervisor-related commitment, and gender. Journal of Emerging Leadership Journeys 1 (4), 21-25.

33. Ratyan, T., \& Mohd, A. (2013). Overview of Path-Goal Leadership Theory. Comprehensive Research Journals, 1(1), 1-5.

34. Robbins, S. P. (2005). Organizational Behavior (1 $11^{\text {th }}$ Ed.) Pearson Prentice-Hall, Englewood Cliffs, N.J.

35. Robbins, S. P. (2014). Organizational Behavior (16 $6^{\text {th }}$ Ed.). Upper Saddle River: Prentice Hall.

36. Shafritz, J. M. (2010). Introducing Public Administration. Philadelphia: Longman Inc.

37. Suradi, A. (2017) examined and analyzed the effect of leadership style and Organizational Culture on Lecturer's job satisfaction in Russia. Russian Journal of Agricultural and Socio-Economic Sciences, 1 (1), 12-13

38. Taris, T. W. (2016). Is there a relationship between burnout and objective performance? A critical review of 16 studies: work and stress, Journal of Humanities, 20(3), 316-334.

39. Temple, J. C. (2013). A Quantitative Study of Factors Contributing to Perceived Job Satisfaction of Information Technology Professionals Working in California Community Colleges. Doctoral Dissertation. University of La Verne.

40. Titko, J., \& Lace, N. (2015). Customer satisfaction and loyalty in Latvian retail banking. Economics \& Management.

41. Tomaževič, N., Seljak, J. \& Aristovnik, A. (2014). Factors influencing employee satisfaction in the police service: the case of Slovenia. Journal of Social Sciences 6(1), 64-73.

42. Vroom, V.H. (1964). Work and motivation. New York: Wiley.

43. Yang, X., W. Wang, (2013). Exploring the Determinants of Job Satisfaction of Civil Servants in Beijing, China. Public Personal Management. Journal of Management, 2 (1), 2-3.

44. Yukl, G. A. (2013). Leadership in Organizations ( $7^{\text {th }}$ Ed.). Englewood Cliffs, NJ: Prentice Hall. 